\title{
Refuge
}

Canada's Journal on Refugees

revue canadienne sur les réfugiés

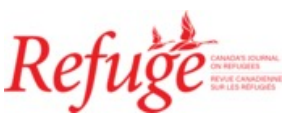

\section{Forensic Age Estimation in Swiss Asylum Procedures: Race in the production of age}

\section{Johannes Balthasar Oertli}

Volume 35, Number 1, 2019

Racialized Refuge

URI: https://id.erudit.org/iderudit/1060671ar

DOI: https://doi.org/10.7202/1060671ar

See table of contents

Publisher(s)

Centre for Refugee Studies, York University

ISSN

0229-5113 (print)

1920-7336 (digital)

Explore this journal

Cite this article

Oertli, J. (2019). Forensic Age Estimation in Swiss Asylum Procedures: Race in the production of age. Refuge, 35(1), 8-17. https://doi.org/10.7202/1060671ar
Article abstract

In asylum procedures, authorities often doubt the claim of an unaccompanied young person to be a child. In Switzerland, in such cases, asylum seekers are made to undergo forensic age estimation to assess their "actual" age. This article studies this practice, drawing on interviews with the people who commission and conduct it. It elaborates on what triggers such "age disputes" and explains how age is being assessed. It continues by highlighting the difference between forensic and medical age estimation and how the use of FAE in a forensic environment racializes the children involved. In conclusion, this article reflects on the meaning of this racialization and what it, as well as the use of FAE, signifies about the interplay of racialized boundaries and legal borders within current migration regimes.
Copyright (c) Refuge: Canada's Journal on Refugees, 2019

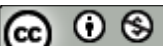

This document is protected by copyright law. Use of the services of Erudit (including reproduction) is subject to its terms and conditions, which can be viewed online.

https://apropos.erudit.org/en/users/policy-on-use/ 


\title{
Forensic Age Estimation in Swiss Asylum Procedures: Racialization in the Production of Age
}

\author{
JOHANNES OERTLI
}

\section{Abstract}

In asylum procedures, authorities often doubt the claim of an unaccompanied young person to be a child. In Switzerland, in such cases, asylum seekers are made to undergo forensic age estimation to assess their "actual" age. This article studies this practice, drawing on interviews with the people who commission and conduct it. It elaborates on what triggers such "age disputes" and explains how age is being assessed. It continues by highlighting the difference between forensic and medical age estimation and how the use of FAE in a forensic environment racializes the children involved. In conclusion, this article reflects on the meaning of this racialization and what it, as well as the use of FAE, signifies about the interplay of racialized boundaries and legal borders within current migration regimes.

\section{Résumé}

Dans les procédures de demande d'asile, les autorités doutent souvent de la prétention de jeunes personnes nonaccompagnées à être des enfants. En Suisse, dans de tels cas, les demandeurs d'asile sont soumis à une procédure d'estimation médico-légale afin d'évaluer leur âge "réel». Cet article étudie cette pratique à partir d'entretiens approfondis avec les personnes qui la commissionnent et la mettent en oeuvre. Il traite des raisons provoquant ces contestations sur lâge et explique la façon dont lâge est évalué. Il souligne ensuite la différence entre une estimation médico-légale et médicale ainsi que la manière dont l'estimation de l'âge en milieu médico-légal racialise les enfants concernés. L'article se conclut par une réflexion sur la signification de cette racialisation et sur ce que cette dernière, de même que l'utilisation de l'estimation médico-légale, signifient au sujet de l'interaction entre frontières racialisées et frontières juridiques dans les régimes migratoires actuels.

I n Switzerland there are significant advantages to being considered an unaccompanied asylum-seeking child (UASC). They range from better reception conditions and care to being protected from deportation to the country of first entry under the Dublin III regulation. Thus authorities presuppose an incentive for adolescent asylum seekers to falsely claim to still be UASC and in turn to contest these

Cette œuvre en libre accès fait l'objet d'une licence Creative Commons Attribution-NonCommercial 4.o International License, laquelle autorise l'utilisation, la reproduction et la distribution de l'œuvre sur tout support à des fins non commerciales, pourvu que l'auteur ou les auteurs originaux soient mentionnés et que la publication originale dans Refuge: revue canadienne sur les réfugiés soit citée. 
claims. Indeed, since the peak of asylum applications in the "migration crisis" in 2015, ${ }^{1}$ there has been more scrutiny of age disputes. Adolescent applicants have become increasingly entangled in legal disputes over their "true" age. ${ }^{2}$ Age has become a complicated category for young asylum seek$\mathrm{ers}^{3}$ and the Swiss Secretariat for Migration (SEM), each attempting to prove opposite claims. For solutions, the SEM approached forensic medical practitioners, who perform a procedure known as forensic age estimation (FAE), wherein different parts of a young person's body are measured and categorized. ${ }^{4}$ FAE establishes a probable age range of UASC, which authorities take to settle age disputes.

This article unpacks FAE in Swiss asylum procedures, focusing on one particular procedure called three-pillar analysis. It draws upon research conducted in Switzerland in the summer of 2016. I base my work on eight interviews lasting around one hour with specialists in $\mathrm{AE}$, conducted between April and June 2016. The interviews were translated from German to English and anonymized. My interlocutors can be divided into two groups. I spoke with three individuals who commission or carry out tests and five people who are critical of the tests. This imbalance emerged because few people conduct FAE in Switzerland and because I struggled to find interview partners in favour of FAE, but not to find people opposed. While forensic age estimations (as well as other forms of age estimations) ${ }^{5}$ have been a focus of scientific inquiry (in particular, legal), ${ }^{6}$ little social science research has covered the issue, and much of it has focused solely on the procedure in theory, ${ }^{7}$ or on its participants. ${ }^{8}$ This article analyzes interviews with the people who commission and conduct FAE and thus centres on FAEs in practice.

I complement the interviews with a close reading of an expert report on age estimation (Altersgutachten): the written product of FAE. Accessing such reports was difficult. However, I gained access to one report through an NGO worker. I used it to challenge and complement the interviews. It is anonymized and translated from German. Even though I read only one report, my interviews, as well as the academic literature the report cites, confirm the procedure detailed in it. The report will be used only to illuminate how FAES proceed. I did not meet the young person whose body this report assesses. I know the subject is male, from Eritrea, and claimed to be sixteen at the time of the assessment, and the report led to his being re-estimated as adult.

This article elaborates on the reasons for such "age disputes." Explaining how age is being determined, I continue to illuminate how FAE is different from medical age estimation conducted in a clinical context. I highlight how clinical and medical age estimation assess chronological or biological age respectively. ${ }^{9}$ I continue by focusing on one specific moment in FAES, where this difference in context demands that FAE adapts its reference population. This leads it to draw upon a racist categorization. In this moment, the test racializes its subjects to uphold its validity in an asylum context. In conclusion, this article reflects on the broader meaning of moments like this and how they, as well as the use of FAE, illuminate the ways in which sovereign "borders and [racialized] boundaries" ${ }^{10}$ operate in the current migration regime. ${ }^{11}$

\section{Age Disputes}

The question of age is pivotal in asylum procedures, as everything, including the refugee definition, "must be interpreted in an age ... sensitive manner." ${ }^{\prime 2}$ For example, the same illtreatment amounts to persecution when faced by a child but not by an adult. ${ }^{13}$ In addition, children enjoy the additional protection of the Child Rights Convention. ${ }^{14}$ Furthermore, even though no young person is forced to consent to an FAE, non-cooperation can amount to a breach of the applicant's duty to cooperate. ${ }^{15}$ In the worst case, this can result in dismissal of the asylum procedure or at least will lower the overall credibility of the applicant and thereby influence the asylum decision. Kvittingen has uncovered this possibility in UK age estimations. ${ }^{16}$ Moreover, Swiss asylum law includes many procedural advantage $\mathrm{s}^{17}$ and mandates better housing and care for UASC. ${ }^{18}$ Thus being underage entails different treatment for asylum seekers. Further, the Dublin III regulation protects children from being transferred back to their country of first entry. They are entitled to an asylum procedure in Switzerland. Thus being a child is decisive for an UASC's future, and "age" is a vital procedural (considering the advantages of being UASC), financial (considering the costs of special treatment), and political (considering asylum statistics) issue. ${ }^{19}$

However, all my interlocutors acknowledged that age, despite its imhportance, is difficult to determine. As my interview partner working for the SEM explained, it constitutes a juridical dilemma. Sebastian is a senior case worker at the SEM. He responded to my official interview request to the SEM and wanted to discuss three-pillar analyses (the particular age estimation procedure discussed here) because they are a novel matter for the sEm. He explained why he chose FAE: "As a governmental organization, we are bound to the principle of judicial investigation. We must establish the facts and investigate the circumstance as much as possible. And I considered it my responsibility-as the person, who ... in the end signs the decisions-if we have the possibility to clarify age with such precision as the forensic medical specialists promise, we must use it."

He clarified that the reasons people cannot show proof of being a minor, like a passport or birth certificate, are plenti$\mathrm{ful}^{20}$ and range from lack of bureaucratic structures in their 
country of origin to ill-advice by smugglers ${ }^{21}$ Some are also just informed enough to present themselves as younger than they are. In Sebastian's view, such incentives to cheat and the falsifiability of any proof destabilize every claim of adolescence. However, Sebastian considers it the sEm's obligation-as a government organization-to approach the truth as closely as possible. And he insisted that only faE promises to assess age precisely enough to solve age disputes in a "scientific" manner, which adheres to "the principle of judicial investigation." Likewise the Swiss Regulation on Asylum refers to the possibility of verifying applicants' claimed age using "scientific methods," ${ }^{22}$ and the Swiss Federal Council, whenever asked by MPS about the validity of FAE, replies that there is no reliable method, but FAE is at least based on "scientific methods." 23

Age, Sebastian insisted, is assessed not only by using FAE. In fact, FAE constitutes only a weak indicator. ${ }^{24}$ Identity papers and the statements of the young person and physical appearance are also considered. Besides, according to longstanding judicial practice, ${ }^{25}$ age must be established as part of an overall estimation that considers all possible evidence, because no method is precise enough. ${ }^{26}$ However, as Sebastian himself explained, all evidence apart from FAE is falsifiable, or (in)voluntarily lacking. Furthermore, the burden of proof for being underage rests on the young person. Therefore if minority is implausible, majority is simply assumed. ${ }^{27}$

If the SEM assesses a UASC as adult, the young person's age is preliminarily adjusted to "adult." The final decision is taken only with the asylum decision (and can, therefore, be appealed only then). However, applicants can request adjustment of their personal data in the national registry of asylum seekers. In practice, this is rare, as accessing legal aid for ageadjusted young asylum seekers is hard.

The quote from Sebastian exemplifies that the SEM is unable to decide about age in a way that complies with the principle of judicial investigation. Therefore when Sebastian has a doubt, he turns to an Institute of Forensic Medicine, where forensic practitioners claim to establish age more precisely. Using FAE (a "scientific method") allows him to overcome the age dilemma. Sebastian highlights how the inability to prove "age" by both the SEM and the applicants beyond any doubt triggers age disputes-which are not only about age, but also about the allocation of resources and protection.

Therefore forensic age estimation differs from clinical age estimation, in which the same methods are practised daily and where they were developed. ${ }^{28}$ In a clinical context, age estimations are conducted with "the purpose of preventing, diagnosing, or treating." ${ }^{29}$ Yet, in a forensic context (like asylum procedures), FAEs are also used in criminal procedures, ${ }^{30}$ in particular concerning the question of age of criminal responsibility (and, thus, imprisonment) ${ }^{31}$ as well as in family law ${ }^{32}$ - they answer different questions. In clinical contexts, the chronological age of the child is always known (or at least not contested). And chronological and biological age are compared only as an indication of potential bodily disorders, not to establish adulthood. The doctor evaluates whether a child's physical development corresponds with the average development within its age group. If it does not, the child might be ill. As such, the test does not intend to establish clear boundaries but only to identify stark discrepancies. On the other side, in (non-clinical) FAE, if the test result and the UMA's claim are incompatible, FAE concludes that the professed age of the child does not correspond to its factual age. Thus its stated age becomes implausible: the child might be lying. The comparison of test result and declared age no longer evaluates the health of the child, but rather assesses the credibility of the test subject. And this estimation needs to be much more (numerically) precise in order to deliver significant results-results that enable Sebastian to settle an age dispute.

\section{Forensic Age Assessment}

FAE is a complicated procedure, opaque to its subjects. At their core, age estimations compare the development of a specific part of the body of a young person whose age is unknown to the development of the same body part of a reference group, where everyone's age is known. In this way, it determines a likely range within which the young person's age in all probability falls. Thus faE produces specific knowledge - a biological numeric age range-from the young person's body.

There are two different forms of forensic age estimation in Switzerland. Both happen, in most cases, shortly after arrival in Switzerland, when a case worker contests the claimed age on the basis of physical appearance or behaviour. Most commonly, a general doctor analyzes an X-ray of the left wrist bone, using a method developed by Greulich and Pyle ${ }^{33}$ in a hospital or by a GP. ${ }^{34}$ Yet this procedure has been criticized by medical associations for its imprecision. ${ }^{35}$ While it is still being used, the SEM started testing a new method of age estimation-the so-called three-pillar analysis-which they intend to roll out throughout Switzerland as part of a new accelerated asylum procedure that came into effect in March 2019. ${ }^{36}$

Three-pillar analyses are different, as they compare and categorize three body parts (one for each pillar): wrist bone development, dental maturity, and sexual maturation. ${ }^{37}$ Three-pillar analyses are conducted by forensic scientists in university institutes of forensic science. FAE establishes a result for all three pillars and then mathematically merges 
them into one combined result. In that way, according to my interlocutors, it assures greater accuracy and a holistic estimation of a child's body.

All three body parts are similarly assessed. For example, following the report, the young person's sexual maturity is categorized using the stages of Marshall and Tanner. ${ }^{38}$ Practitioners visually compare what they see to an image and a description for each stage. The young person's primary sexual organs are classified at stage $\mathrm{G}_{5}$ (stage 5 genitalia): "genitalia adult in size and shape." ${ }^{39}$ This taxonomy differentiates between five stages of development for genitalia (boys) or breasts (girls), as well as pubic hair. They range from stage 1 "pre-adolescent" to stage 5 "adult." 40 G5 indicates an average age of $14.92( \pm 1.10)$ years, i.e., an age range from 13.82 to 16.02 years. Secondary sexual characteristics are ranked at stage $\mathrm{PH} 5$ (stage 5 pubic hair), which equates to an average age of 15.18 years, with a margin of error of 1.07 years. This categorization stems from data of 192 girls and 228 boys from the Harpenden Growth Study, a longitudinal study from 1948 to 1971 where a changing group of adolescent white British boys and girls from a lower-class background living in a children's home in Harpenden, north of London, were examined and photographed (naked) every three months for up to fifteen years each. ${ }^{41}$

The other pillars are similarly assessed, using a different classification. After all three pillars have been analyzed and an age range has been determined for each, they are mathematically combined into a final result. This is done by calculating the average of the two minimum ages (i.e., average age minus margin of error) of the skeletal and the dental assessment. The third pillar, sexual maturation and anthropometric measures, is-according to my interviewees-referenced only to exclude any bodily issues that influence the test. In the report, no such factors were detected. Thus, in a first step, FAE determines three different age ranges of the young person's body, which are then combined into one result. In other words, it establishes the young person's biological age.

In a second step, this combined result is then compared to the claimed age of the young person. In the report, the combination amounted to a minimum (biological) age of 16.5 years. ${ }^{42}$ In comparison, the young person's claimed chronological age ( 15.9 years at the time of the test) is considered "incompatible." "Based on the combined age diagnostic ${ }^{43}$ and for the benefit of the person concerned, in consideration of the lowest singular result, which are not contradictory, at the time of assessment, for $\mathrm{xxx}$ the certain completion of the 16 th year of life ( 16.5 years) can be concluded. Therefore, the indicated age of about 15 years and 11 months [ 15.92 years] is not compatible with the result of the forensic age estimation."

Unlike in a clinical context, FAE needs an exact result against which it can compare the young person's contested chronological age. Yet clinical age estimation is a statistical assessment of how much a body corresponds to its age average. ${ }^{44}$ Thus clinical and forensic age estimation answer two different questions. Noll considers this a type III error ("the expert gives the correct answer, but to the wrong question"). ${ }^{45}$ In other words, to him forensic age estimation answers a question about biological age ("Is this young person healthy?"), which is different from the question about chronological age being asked ("Is this young person a child?"). However, the different approach-the scientific-ness-is exactly why the SEM turns to forensic scientists. Thus, as I will argue, it is not so much that FAE answers a question different from the one asked by the SEM. Instead, FAE adapts its test in order to respond to the question asked.

\section{Influence of Ethno-Racial Ascription}

FAE has to adapt the reference population to match an asylum context. This adaptation not only racializes the young people assessed by FAE but also highlights the wider implications of the attempt to match clinical age estimations to an asylum context. In general, FAE compares a young person's body part to the same body part of a reference population. Max explains that this reference population must comprise an optimal population. He is a forensic practitioner and conducts three-pillar analyses with UASCs. He contacted me after I approached his institute with a formal interview request. "The reference study always encompasses an optimal population; that is, persons who develop as well and as fast as possible, who simply do not have any influencing factors like a long illness or hunger."

Optimal reference populations rule out factors that lower bodily development. If a person who has suffered hunger (and thus developed more slowly) is compared with a group who has not suffered hunger (and thus developed more quickly), FAE will estimate that they are younger, to their advantage. To Max, this method assures that FAE never overestimates anyone's age (thereby denying needed protection). However, optimal reference populations also enable FAE to assess people from different contexts and backgrounds. All reference populations of the three pillars (wrist, teeth, and sexual maturation) comprise white European children (or children of white European descent). In the example of sexual maturation, the population encompassed white British boys and girls from Harpenden, UK.46 Similarly, Greulich and Pyle's standards are based on white children of European descent from the Cleveland area. ${ }^{47}$ None of them suffered from malnutrition, and all were considered to be in good health.

Yet in practice and in the vast majority of cases, FAE is used on young people of colour. The question of comparability of young people from different origins is raised in the literature, ${ }^{48}$ but also by my interview partners (critical of FAE 
and not). In my interviews with forensic practitioners, we touched upon the influence of "ethnicity," and their answers struck me.

The report at hand discusses this possible influence of the test subject's origin-he is Eritrean-on the test result in a section titled "Influence of Ethnic Affiliation." First, the report determines that everyone passes through the same stages of development and thus affirms comparability between "ethnic groups." Next, it establishes that everyone passes through bone age and sexual maturation at the same time. The report goes on to cite "evidence" that wisdom teeth of children of different ethnicities develop at different ages. Hence, it concludes the ethnicity of the reference group for dental age needs adaptation when FAE estimates young people of different "ethnic affiliations." Thereby, this "ethnic affiliation" assumes the power of a biologically defined reference group. The report continues to consider what this signifies for Eritreans:

In Eritrea, there are nine larger ethnic groups. On the one part, there exist no generally accepted reference studies for Eritrean populations on tooth development, on the other part, owing only to the external appearance in the case at hand, neither the exact ethnicity nor the proportion and possible influence of a mixed ethnic origin can be concluded. However, the person affected can readily be assigned to Sub-Saharan Africa.

In a study by Olze et al., relevant differences of the established average age before the completion of root growth (stages D-G) between German, Japanese and South African populations could be demonstrated. ${ }^{49}$ Thus, wisdom teeth development of the South African population occurred approx. 1 year faster than in the German comparison group, which, in turn, [developed] faster than in the Japanese. Liversidge was also able to identify through a comparison of Black people from South African populations and populations from London a significantly earlier wisdom tooth development of the African population. ${ }^{50}$ In this respect, in the case at hand, the age estimation is based on the reference data of a South African population. ${ }^{51}$

For lack of reference populations from Eritrea and because the practitioner is unable to determine the subject's exact ethnicity beyond doubt, the person is "assigned to Sub-Saharan Africa." As both Olze and Liversidge found that "South African teeth" develop faster than teeth of European children, the reference group is exchanged for a reference population from South Africa, and the subject is compared to South Africans or more exactly a reference group of " 584 black South African subjects." ${ }^{2}$ From "Eritrean," stated by the young person himself on his personal details form, he has now been ascribed to "black South African." He has been "readily" attributed "black."
The direct consequences of this shift are hard to assess, because the original study of Demirjian in 1973 did not extend beyond 16 years (as their data included only 109 children between 15.5 and 18 years).$^{53}$ In the case here, the underlying dataset is changed "in favour" of the age-disputed individual, as Olze found that the wisdom teeth of a South African population develop earlier than in the reference population underlying the stages of Demirjian, which comprised "1446 boys and 1482 girls [from ...] Montreal [... with] parents and grand-parents of French Canadian origin." ${ }^{54}$ Yet in Olze's study, the difference between the "German" and the "South African" reference group is to the subject's disadvantage. In the male German reference group mineralization stages "F" (what was found for the report's subject's wisdom teeth) amounted to an average age of $18.2 \pm 2.1$, whereas those for "South African males" equated to $18.7 \pm 2.3 .{ }^{55}$

What is clear, however, is that the lack of a suitable reference group as well as the inability to pinpoint the young person's ethnicity, to determine it in a way that cannot be falsified by the test subject-in other words without having to trust his word-led the person who conducted the test to redefine the subject's ethnicity from Eritrean to "black." He was ascribed Blackness and racialized. I insist on "ascribed," because in this moment Blackness was also created by the fact that the forensic practitioner in charge was required to fall back upon "grand ethnicities" - considering that my interlocutors differentiated between "European," "Asian," and "African" - to make the category of ethnicity meaningful in this specific context. As Miles insists, racial categories do not exist: "There are no 'races' and therefore no 'race relations.' There is only a belief that there are such things, a belief which is used by some social groups to construct an Other (and therefore the Self) in thought as a prelude to exclusion and domination, and by other social groups to define Self (and so to construct an Other) as a means of resisting that exclusion." ${ }^{56}$

He highlights how racialization is constructing an Other in order to exclude it. Wodak and Reisigl highlight the point that, for Miles, racialization is a "process of categorization and meaning construction in which specified meanings are ascribed to real or fictitious somatic features." ${ }^{37}$ This theorization helps to shed light on why the practitioner manages only to pinpoint the subject's ethnicity beyond doubt, once the reference group had been changed; the new ethnicity was "readily" [ohne Weiteres] ascribed. Wallman explains her unease with this category of "ethnicity," highlighting the fact that "ethnic" boundaries are always far from self-evident and more about "the meaning put upon difference," that is the decision on where to draw the line. ${ }^{58}$ As Werbner helps to understand, the meaning of the ethnicity "Eritrean" (stated by the young asylum seeker on the personal details from the 
beginning of his asylum procedure) is very different from the meaning the ethnicity acquires once the forensic scientist has put meaning upon it (i.e., made it useful in the context) by ascribing Blackness to the young person's body. Whereas the former constitutes a self-identification, the latter is a "reification," a "representation which distorts and silence[s]."59

Thus ethnicity was reified into "black." It became meaningful for FAE, because for "black" bodies, unlike for Eritrean bodies, a reference population exists. The "new ethnicity" allows the test to settle age disputes. However, it was also made meaningful in another way. It changed "ethnicity" from a self-identification to an external ascription of ethnic origin. In other words, the test, when faced with its own need to ascribe ethnicity to produce the demanded objective knowledge in a scientific way (to produce knowledge that settles age disputes) and its inability to do so, ascribes (and creates) an "ethnic affiliation" to make "ethnicity" "significant": it racializes the subject to an all-African Blackness. It reduces, as Hesse poignantly formulates, a "diverse cultural representation to the limited iconography of 'races." 60

The category of ethnicity - the validity of which as a category of self-identification is not at issue here-when used in the context of FAE becomes synonymous with "race." The adjusting of the reference group thereby comes to resemble a discursive move that Balibar calls "differential racism"-a move away from "race" to a static "culture" that hides the underlying racist assumptions. ${ }^{61}$ In a similar way, Lentin insists that the "scientific status attributed to ethnicity as a replacement for race contributes to the neglect of the persistence of racism in contemporary society." ${ }^{2}$ "Scientific" ethnicities (untainted by history) become a proxy for race. ${ }^{63}$ The "readily" ascription of the racialized category of ethnicity by the forensic practitioners to the young people's bodies-and references to scientific journals that provide them with a justification to hide behind-conceals FAE's support of racial categorizations.

And, returning to Miles, racialization is always the "racialisation of social relations," ${ }^{\prime 4}$ which shifts focus to the consequences of this racializing of the test subject. FAE's search for "an ethnic factor" highlights the fact that racism does not imply reference to biological difference. To the contrary, racism is the conversion of social "patterns of discrimination" into biological differences. ${ }^{65}$ Racializing the young people involved allows FAE to be used in a context it is not made for. It permits the establishment of a minimum age "in an objective way," that is a minimum age that is claimed to be "precise enough" to solve an age dispute. Yet if FAE establishes age according to a comparison with a reference population, it assesses how much a body conforms to age averages (of ascribed and constructed "ethnic groups"). In other words, FAE excludes young people of colour whose bodies do not correspond to the ideal type of a child's body (that is, a white childish body) from the protection of being a child. And as such it stands in a long tradition of ways Europe has excluded "threatening" Black bodies. Therefore, FAE highlights how racism is a process by which racialized others are produced and simultaneously confirmed, ${ }^{66}$ and how it hides the social relations behind it of who is inside and who is outside-of which child receives the protection of the state and which receives the full force of its politics of exclusion.

\section{Conclusion}

This article showed how age is crucial in asylum procedures. Yet for the SEM it constitutes a judicial problem, as they regard themselves unable to assess it adequately by themselves. Thus, they turn to forensic scientists, as FAE promises to assess age in a way that fulfills the SEM's duty to adhere to the principle of judicial investigation. However, the way faE estimates a person's age glosses over the fundamental difference between clinical and medical age assessment. Whereas clinical age estimation works with a known chronological age, FAEs are commissioned because the chronological age is contested. Thus, while clinical age estimation searches only for discrepancies as indicators of illness, in FAE the comparison needs to be much more precise for the test to be useful to the FAE, to make it meaningful in a particular context and to solve an age dispute. In other words, FAE, as the use of clinical age estimation methods in an asylum (or forensic) context, requires more precision to assess whether or not a young person is a child or not.

However, this demand for precision racializes the young people involved. The specific demands that the test represents require FAE to construct an "ethnic affiliation" synonymous with race. FAE, as a racialized procedure, comes to exclude certain bodies from the protection that children are entitled to, not along age lines, but rather along lines of conforming or not to a normalized bodily image of what a "black" child looks like.

The racialization in FAE highlights how racism is a tool for exclusion and for justification. On the one side, it is another (racialized) layer of exclusion built into the immigration system. Yet, on the other, racism is to the "accuser's benefit and at his victim's expense." ${ }^{37}$ In FAE, the racialization not only enables the use of forensic age estimations in asylum procedures, it also legitimizes the practice of assigning some young people the protection of being considered a child, while others are being transferred to their country of first entry under the Dublin III agreement. It does so by excluding those who conform to standardized (bodily) notions of childhood, while excluding those who do not. Lentin explains that this silence on race enables (in her example) the atrocities of the war on terror to continue, while still upholding the idea of 
a Europe based on humanity. ${ }^{68}$ Park highlighted a similar consequence in the racist representation of the case of Omar Khadr, an underage Guantanamo detainee, in Canadian media. ${ }^{69}$ The racialization allows Omar to be excluded from the protection of the law he is entitled to as a Canadian citizen while at the same time upholding Canada's own civility. Therefore racializing the young people in FAE allows for the coexistence of enforcement and protection. ${ }^{70}$ It reconciles two clashing state logics. And thus the racialization of the young person's body balances the obligation of the state as the "corporate parent" of said UASC with increasingly punitive migration controls. FAE simultaneously represents and hides the exclusionary practices inherent in the current migration regime. It legitimizes the exclusion of vulnerable people at Switzerland's gates while upholding the idea of a humanitarian tradition.

To finish off, I would like to return to the question of credibility. FAE is also an assessment of the credibility of those who undergo its procedure: the credibility of a young person's claimed age ("Is the combined minimum age compatible with the claimed age?"). And, considering it is always a case worker's suspicion that triggers FAE, it is also an assessment of the overall credibihlity of the asylum seeker. When I asked Sebastian what would happen if a young person refused to undergo FAE, he responded that it would be a breach of the person's duty to cooperate (and, in turn, have implications for the applicant's credibility assessment). In like manner, Kvittingen (and others) ${ }^{71}$ uncovers that the mere fact to be an "age-disputed USAC" can already harm a young asylum seeker's credibility. ${ }^{72}$ Reified ethnicity-or, as I would suggest, the racist use of the self-identification as ethnic Eritrean in the context of FAE (where it becomes synonymous for "black")- "distorts and silence[s]" the subject. ${ }^{73}$ Through FaE it becomes easier to cast the (now racialized) Other as lying, as an "imposter-child" and, in turn, a "bogus refugee." 74

And last, age, I hope it has become clear by now, remains a political question. And the SEM, by trying to overcome the dilemma about the assessment of age, not only outsources the problem but also racializes the child involved. However, it legitimizes the simultaneous concurrence of exclusion and inclusion, upholding a self-image of liberal values while simultaneously excluding people through illiberal practices. FAE contributes to this regime by drowning the "imperial topography," ing to "the characteristics of the bodies involved." I would suggest that this shows how racism maintains what Hesse calls "white governmentalities," and how the governmentality of the European border regime ensures that "the policing of ... borders" coincides with the "production of racialised boundaries." ${ }^{36}$ Thereby it refocuses the centrality of racism in migration regimes as it ensures that protection is being granted only to those who are "not only in but of Europe."77

\section{Notes}

1 Staatssekretariat für Migration (SEM), "Unbegleitete Minderjährige Asylsuchende in Der Schweiz (UMA): Statistiken / Vergleichstabelle" (Bern: Staatssekretariat für Migration, 2018), https://www.sem.admin.ch/dam/data/sem/publiservice/statistik/asylstatistik/statistiken_uma/uma-2017-d .pdf.

2 In spite of its importance, the SEM does not count age disputes (or age estimations), according to the SEM's statistics bureau. It is, therefore, impossible to say how many USAC get caught in age disputes. However, my experience doing case work and research indicates that FAEs are the decisive piece of evidence more often than not. My interviews partners confirmed the same.

3 I speak of children as people under eighteen years and of young person if age is either unclear or irrelevant. See Debbie Busler, Katrina Cowell, Helen Johnson, and Jacinta Kane, "Age Assessment Guidance" (Manchester: Association of Directors of Children's Services, 2015).

4 At the time of this research, I worked in a migrant advisory centre in Berne, Switzerland. I encountered faE through several young people who came to our office. The SEM had assessed them as adults using FAE. Yet they claimed to be children.

5 See, amongst many, C.A. Michie, "Age Assessment: Time for Progress?," Archives of Disease in Childhood 90, no. 6 (2005): 612-13; Colin Michie, "Age Assessment in Adolescents: Why Is It Needed?", Adoption \& Fostering 29, no. 4 (2005): 79-81; Debbie Busler, "Psychosocial Age Assessments in the UK," Forced Migration Review 52 (2016): 86-8; S.J. Cemlyn and M. Nye, "Asylum Seeker Young People: Social Work Value Conflicts in Negotiating Age Assessment in the UK," International Social Work 55, no. 5 (2012): 675-88; Jill Benson, "Age Determination in Refugee Children," Australian Family Physician 37, no. 10 (2008): 821-24; and Sophie Gower, "How Old Are You? Ethical Dilemmas in Working with Age-Disputed Young Asylum Seekers," Practice 23, no. 5 (2011): 325-39.

6 Joël Olivier Müller, “Nichts Genaues' Weiss Man Nicht: Altersbestimmung Im Schweizerischen Asylverfahren," Jusletter, 20 March 2017, 1-54; Emanuele Sironi, Joëlle Vuille, and Franco Taroni, "Estimation forensique de lâge des jeunes migrants - Une note sur la scientificité des méthodes employées en Suisse," Jusletter, 8 October 2018, 29; Matthias Plattner, "Die Altersbestimmung bei unbegleiteten minderjährigen Asylsuchenden unter rechtlichen Gesichtspunkten" (University of Basel, 2017), https://ius. unibas.ch/fileadmin/user_upload/ius/11_Upload_Personenprofile/o3_Titularprofessuren/Uebersax_Peter/Seminararbeiten/Seminararbeit_Plattner_Matthias_Altersbestimmung_def.pdf; Henriette D.C. Roscam Abbing, "Age 
Determination of Unaccompanied Asylum Seeking Minors in the European Union: A Health Law Perspective," European Journal of Health Law 18, no. 1 (2011): 11-25; MarieBénédicte Dembour, "Surely Not! Procedurally Lawful Age Assessments in the UK," in Unaccompanied Children in European Migration and Asylum Practices, edited by Mateja Sedmak, Birgit Sauer, and Barbara Gornik, 155-82 (London: Taylor and Francis, 2017); Denise Venturi, “The Prominence of the Body as an Instrument of Border Control: Assessing the Age of Unaccompanied Migrant Children in the European Union," 2014, Global Campus Open Knowledge Repository, https://repository.gchumanrights .org/handle/20.500.11825/468.

7 Gregor Noll, "Junk Science? Four Arguments against the Radiological Age Assessment of Unaccompanied Minors Seeking Asylum," International Journal of Refugee Law 28, no. 2 (2016): 234-50; Anna Verley Kvittingen, "Negotiating Childhood: Age Assessment in the UK Asylum System," Working Paper Series (Oxford: Refugee Studies Centre, 2010); and Ertug Altinay Rustem, “This Child, Whose Bone Age Is Fourteen...: Ethical Dimensions of Skeletal Age Assessment," International Journal of Feminist Approaches to Bioethics 2, no. 1 (2009): 165-73.

8 Laura Otto, "Ethnographic Insights into the Age Assessment for Young Migrants in Malta," Transnational Social Review 6, no. 1-2 (2016): 187-91; Laura Otto and Margrit E. Kaufmann, “'Minderjährig', 'männlich'-'stark'? Bedeutungsaushandlungen der Selbst- und Fremdzuschreibung junger Geflüchteter in Malta. Eine intersektionelle Leseweise ethnografischer Forschungsausschnitte," GENDERZeitschrift für Geschlecht, Kultur und Gesellschaft 10, no. 2 (2018): 63-78; Heaven Crawley, "When Is a Child Not a Child? Asylum, Age Disputes and the Process of Age Assessment" (London: Immigration Law Practitioners' Association, 2007); Carly McLaughlin, “'They Don't Look like Children': Child Asylum-Seekers, the Dubs Amendment and the Politics of Childhood," Journal of Ethnic and Migration Studies 44, no. 11 (2017): 1757-73; and Evan Smith and Marinella Marmo, "Examining the Body through Technology: Age Disputes and the uk Border Control System," Anti-Trafficking Review 2 (2013).

9 Biological age represents a person's bodily function "with respect to his [or her] potential life span," while chronological age comprises of the number of years, months. and days since birth. See Richard A. Settersten and Karl Ulrich Mayer, "The Measurement of Age, Age Structuring, and the Life Course," Annual Review of Sociology 23, no. 1 (1997): 239-40.

10 Didier Fassin, "Policing Borders, Producing Boundaries: The Governmentality of Immigration in Dark Times," Annual Review of Anthropology 40 (2011): 213.

11 Following Eule, Loher, and Wyss, I conceptualize the European "migration regime" in contradistinction to a legal regime to draw attention to the "everyday practices of a variety of actors with diverging intentions" in "a conflictual field of interests, negotiations, discourses and struggles on inclusion and exclusion between different actors." See Tobias G. Eule, David Loher, and Anna Wyss, "Contested Control at the Margins of the State," Journal of Ethnic and Migration Studies 44, no. 16 (2017): 2.

12 Un Committee on the Rights of the Child, "General Comment No. 6 Treatment of Unaccompanied and Separated Children Outside of Their Country of Origin" (Geneva: United Nations, 2005).

13 UNHCR, "Guidelines on International Protection: Child Asylum Claims under Articles 1(A)2 and 1(F) of the 1951 Convention and/or 1967 Protocol Relating to the Status of Refugees," Guidelines on International Protection (Geneva: UNHCR, UN Refugee Agency, 2009).

14 UN General Assembly, "Convention on the Rights of the Child," 1577 Treaty Series $₫$ (1989), http://www.refworld .org/docid/3ae6b38fo.html.

15 Schweizerische Flüchtlingshilfe, "Country Report Switzerland: 2017 Update," Asylum Information Database (Brussels: European Council on Refugees and Exiles, 2017), http://www.asylumineurope.org/sites/default/files/reportdownload/aida_ch_2o17update.pdf.

16 Kvittingen, "Negotiating Childhood."

17 Joana Maria Mösch, "Multidisziplinäres Verfahren Unbegleiteter Minderjähriger Asylsuchender," Jusletter, 15 August 2016, 1-28.

18 See ssi, "Mapping Der mNA-Betreuungsstrukturen in Den Kantonen / Plateforme Enfants Migrants," Plateforme Enfants Migrants, 2017, http://www.migrant-children.ch/ de/node/828.

19 SBAA, "Zukunftsentscheide Durch Ungenaue Handknochenanalyse," beobachtungsstelle.ch, 24 June 2014, https:// beobachtungsstelle.ch/fileadmin/pdf/Case256.pdf.

20 See also Kimberly Seibel, "Bureaucratic Birthdates: Chronometric Old Age as Resource and Liability in U.S. Refugee Resettlement," Refuge: Canada's Journal on Refugees 32, no. 3 (2016): 8-17.

21 Noll, "Junk Science?"

22 Article 7(1), Swiss Regulation on Asylum 1.

23 Swiss Federal Council, "Written Comment on Motion 17.3454" (Swiss Parliament, 2017), https:// www.parlament.ch/de/ratsbetrieb/suche-curia-vista/ geschaeft?AffairId=20173454; Swiss Federal Council, "Written Comment on Motion 16.3598” (Swiss Parliament, 2016), https://www.parlament.ch/de/ratsbetrieb/suche-curiavista/geschaeft?AffairId=20163598; Swiss Federal Council, "Written Comment on Motion 16.3613" (Swiss Parliament, 2016), https://www.parlament.ch/de/ratsbetrieb/ suche-curia-vista/geschaeft?AffairId $=20173454$.

24 Swiss Federal Council, "Written Comment on Motion 16.3598."

25 Decision of the Asylum Appeals Commission from 29 October 2004, EMARK 2004/30 (Asylum Appeals Commission 2004); Decision of the Asylum Appeals Commission from 25 May 2005, EMARK 2005/16 (Asylum Appeals Commission 2005). 
26 Swiss Federal Council, "Written Comment on Motion $16.3613, " 361$.

27 Swiss Federal Council, "Written Comment on Motion $17.3454, " 345$.

28 Rustem, “This Child, Whose Bone Age Is Fourteen"; Abbing, "Age Determination of Unaccompanied Asylum Seeking Minors in the European Union."

29 Martina Focardi, Vilma Pinchi, Federica De Luca, and Gian-Aristide Norelli, "Age Estimation for Forensic Purposes in Italy: Ethical Issues," International Journal of Legal Medicine 128, no. 2 (2014): 516.

30 Susan J. Terrio, "New Barbarians at the Gates of Paris?: Prosecuting Undocumented Minors in the Juvenile Court-The Problem of the 'Petits Roumains," Anthropological Quarterly 81, no. 4 (2008): 873-901.

31 Don Cipriani, Children's Rights and the Minimum Age of Criminal Responsibility: A Global Perspective (Abingdon: Routledge, 2009).

32 Andreas Schmeling, Andreas Olze, Walter Reisinger, Michael König, and Gunther Geserick, "Statistical Analysis and Verification of Forensic Age Estimation of Living Persons in the Institute of Legal Medicine of the Berlin University Hospital Charité," Legal Medicine 5 (2003): S367-S71.

33 William Walter Greulich and Sarah Idell Pyle, Radiographic Atlas of Skeletal Development of the Hand and Wrist (Stanford: Stanford University Press, 1959).

34 Simon Jäggi, "Asylverfahren: In Einer Woche Um Drei Jahre Gealtert," Surprise, 22 April 2016, 10-13.

35 Georg Friedrich Eich and Valérie Schwitzgebel, "Knochenalterbestimmung Bei Asylsuchenden Ist Unbrauchbar," Schweizerische Ärztezeitung 97, no. 14 (2016): 507; Sarah Depallens, Fabienne Jäger, and Nicole Pellaud, "Détermination de lâge Des Jeunes Migrants Position de La Société Suisse de Pédiatrie," Paediatrica 28, no. 2 (2017): 3; Nicole Pellaud, Sarah Depallens, and Fabienne Jäger, "Altersbestimmung Junger Migranten," Schweizerische Ärztezeitung 98 (2017): 21-2.

36 Tobias Bär, "Migration: Altersabklärung bei Asylsuchenden: Flüchtlingshilfe wehrt sich gegen 'Genitaltests," St. Galler Tagblatt, 2 December 2018, https://www .tagblatt.ch/schweiz/migration-altersabklaerung-bei-asylsuchenden-fluechtlingshilfe-wehrt-sich-gegen-genitaltests-ld.705235.

37 Andreas Schmeling, Walter Reisinger, Gunther Geserick, and Andreas Olze, "Age Estimation of Unaccompanied Minors," Forensic Science International 159 (2006): S61-S4.

38 W.A. Marshall and J.M. Tanner, "Variations in the Pattern of Pubertal Changes in Boys," Archives of Disease in Childhood 45, no. 13 (1970): 13-23; Marshall and Tanner, "Variations in Pattern of Pubertal Changes in Girls," Archives of Disease in Childhood 44, no. 235 (1969): 291-303.

39 Marshall and Tanner, "Variations in the Pattern of Pubertal Changes in Boys," 14.

40 J.M. Tanner, Growth at Adolescence (Oxford: Blackwell Scientific Publications, 1978), 25.
41 Marshall and Tanner, "Variations in the Pattern of Pubertal Changes in Boys"; J.M. Tanner, A History of the Study of Human Growth (Cambridge: Cambridge University Press, 2010).

42 This is a typo. The result is 16.05 years.

43 Andreas Schmeling, Uta Baumann, Sven Schmidt, KlausDieter Wernecke, and Walter Reisinger, "Reference Data for the Thiemann-Nitz Method of Assessing Skeletal Age for the Purpose of Forensic Age Estimation," International Journal of Legal Medicine 120, no. 1 (2006): 1-4.

44 See also A. Aynsley-Green, "Unethical Age Assessment," British Dental Journal 206, no. 7 (2009): 337.

45 Noll, "Junk Science?"

46 Tanner, History of the Study of Human Growth.

47 Maria Alcina, Alina Lucea, Miquel Salicrú, and Daniel Turbón, "Reliability of the Greulich \& Pyle Method for Bone Age Estimation in a Spanish Sample," Journal of Forensic and Legal Medicine 1, no. 1 (2015): 1-6; Greulich and Idell Pyle, Radiographic Atlas.

48 And often to differing conclusions. For example, Mora, Boechat, Pietka, Huang, and Gilsanz conclude Greulich and Idell Pyle's standards are inapplicable to children of African descent, while Schmeling, Reisinger, Loreck, Vendura, Markus and Geserick determine no significant differences. See Stefano Mora, M. Ines Boechat, Ewa Pietka, H.K. Huang, and Vicente Gilsanz, "Skeletal Age Determinations in Children of European and African Descent: Applicability of the Greulich and Pyle Standards," Pediatric Research 50, no. 5 (2001): 624-8; and Andreas Schmeling, Walter J. Reisinger, David J. Loreck, Klaus Vendura, Wohlschläger Markus, and Gunther Geserick, "Effects of Ethnicity on Skeletal Maturation: Consequences for Forensic Age Estimations," International Journal of Legal Medicine 113 (2000): 253-8.

49 Andreas Olze, Andreas Schmeling, Mari Taniguchi, Hitoshi Maeda, Piet van Niekerk, Klaus-Dieter Wernecke, and Gunther Geserick, "Forensic Age Estimation in Living Subjects: The Ethnic Factor in Wisdom Tooth Mineralization," International Journal of Legal Medicine 118, no. 3 (2004): 170-3.

50 Helen M. Liversidge, "Timing of Human Mandibular Third Molar Formation," Annals of Human Biology 35, no. 3 (2008): 294-321.

51 Olze et al., "Forensic Age Estimation in Living Subjects."

52 Olze et al., "Forensic Age Estimation in Living Subjects," 171.

53 Arto Demirjian, Harvey Goldstein, and Jakob Tanner, "A New System of Dental Age Assessment," Human Biology 45, no. 2 (1973): 211-27.

54 Demirjian, Goldstein, and Tanner, "New System of Dental Age Assessment," 214.

55 Olze et al., "Forensic Age Estimation in Living Subjects," 172.

56 Robert Miles, Racism after "Race Relations" (London: Routledge, 1993), 42. 
57 Ruth Wodak and Martin Reisigl, "Discourse and Racism: European Perspectives," Annual Review of Anthropology 28, no. 1 (1999): 180.

58 Sandra Wallman, "Race Relations or Ethnic Relations?," Journal of Ethnic and Migration Studies 6, no. 3 (1978): 307.

59 Pnina Werbner, "Essentialising Essentialism, Essentialising Silence: Ambivalence and Multiplicity in the Constructions of Racism and Ethnicity," in Debating Cultural Hybridity: Multi-Cultural Identities and the Politics of Anti-Racism, ed. Pnina Werbner and Tariq Modood (London: Zed Books, 1997), 299.

60 Barnor Hesse, "White Governmentality: Urbanism, Nationalism, Racism," in Imagining Cities: Scripts, Signs, Memories, edited by Sallie Westwood and John Williams (London: Routledge, 2005), 99.

61 Etienne Balibar, "Difference, Otherness, Exclusion," Parallax 11, no. 1 (2005): 19-34.

62 Alana Lentin, Racism and Anti-Racism in Europe (London: Pluto, 2015), 29.

63 Alana Lentin, "Europe and the Silence about Race," European Journal of Social Theory 11, no. 4 (2008): 487-503.

64 Miles, Racism after "Race Relations," 42.

65 Wulf D. Hund, "It Must Come from Europe: The Racisms of Immanuel Kant," in Racisms Made in Germany, edited by Wulf D. Hund, Christian Koller, and Mosche Zimmermann, 77-8 (Zurich: LIT-Verlag, 2011).

66 Philomena Essed, Understanding Everyday Racism: An Interdisciplinary Theory (Newbury Park, CA: Sage Publications, 1991).

67 Albert Memmi, Racism (Minneapolis: University of Minnesota Press, 2000), 169.

68 Lentin, "Europe and the Silence about Race," 487.
69 Augustine S.J. Park, "Constituting Omar Khadr: Cultural Racism, Childhood, and Citizenship," International Political Sociology 8, no. 1 (2014): 43-62.

70 See Jacqueline Bhabha, "Minors or Aliens: Inconsistent State Intervention and Separated Child Asylum-Seekers," European Journal of Migration and Law 3 (2001).

71 Heaven Crawley and Emma Kelly, "Asylum, Age Disputes and the Process of Age Assessment," in Safeguarding Children from Abroad: Refugee, Asylum Seeking and Trafficked Children in the UK, ed. Emma O'Kelly, 54-68 (London: Jessica Kingsley, 2012); Erik Malmqvist, Elisabeth Furberg, and Lars Sandman, "Ethical Aspects of Medical Age Assessment in the Asylum Process: A Swedish Perspective," International Journal of Legal Medicine 132, no. 3 (2018): 815-23.

72 Kvittingen, "Negotiating Childhood."

73 Werbner, "Essentialising Essentialism, Essentialising Silence," 299.

74 Stephanie J. Silverman, “Imposter-Children' in the UK Refugee Status Determination Process," Refuge: Canada's Journal on Refugees 32, no. 3 (2016): 30-9.

75 Paul Gilroy, "Raise Your Eyes," opendemocracy.net, 10 September 2002, https://www.opendemocracy.net/faith-911/ article_249.jsp.

76 Fassin, "Policing Borders," 215.

77 Stuart Hall, in Lentin, "Europe and the Silence about Race," 490.

Johannes Oertli has an MA in migration and diaspora studies from SOAS, University of London. He is training as a TV and radio journalist. The author may be contacted at johannes. oertli@gmx.ch. 